\title{
The Emergencies in Bovine Medicine: Situation in the Region of the Centre of Algeria
}

\author{
M. BACHIR PACHA ${ }^{1}$, R.R. TRIKI-YAMANI ${ }^{1}$, R. MOHAMED SAID*2 \\ ${ }^{1}$ Institute of Veterinary Sciences, Laboratory of biotechnology and animal breeding \\ University BLIDA1- (Algeria) \\ ${ }^{2}$ Cellular physiology and Biology department, University Blida 1, Algeria \\ * Corresponding author: rmohamedsaid@yahoo.fr
}

Bulletin UASVM Veterinary Medicine 73(1) / 2016,

Print ISSN 1843-5270; Electronic ISSN 1843-5378

DOI:10.15835/buasvmcn-vm: 10119

\begin{abstract}
The interview of 30 veterinarian's practitioners of the bovine sector, in the region of the center of Algeria, revealed that emergencies affect practically all the big functions. It is, in ascending order decreasing, of pathologies affecting the reproductive tract (metritis and placenta retention) [31\%], the digestive system (meteorisations, enteritis, acidosis, diarrhea and indigestion) [28\%], the musculoskeletal system (whitlow and boiteries) [13 $\%$ ] and other pathologies (Hypocalcemia, RPT, pericarditis, hypomagnesemia and dyes) [17 \%] and finally, the respiratory system (B.P.I.E = Infectious Enzootic Broncho-Pneumonia) [11\%].
\end{abstract}

Keywords: Algeria center, bovine, emergency, medicine

\section{INTRODUCTION}

The veterinary activity is defined as urgent any consultation to be taken without delay. There are two broad categories:

- the true emergency that requires a rapid response of the veterinarian, an immediate gesture, otherwise the animal dies or loses much of its function and,

- the emergency psychological and convenience that represents the vast majority of cases. It is intended to relieve pain or discomfort to the animal or to prevent complications, without that there is a risk to life or a risk of loss of a great function (Brugeres-Picouxj, 2004).

These major emergency requiring treatment medical in cattle are metabolic diseases (neonatal anoxia, puerperal hypocalcemia, tetany of herbage, neonatal anoxia), infectious (neonatal sepsis, neonatal diarrhea, mastitis, diarrhea and neonatal septicemia), accidents of reproduction (dystocia and other problems related to a bad presentation) as well as poisoning.
A good knowledge of these pathologies is therefore indispensable to the practitioner to be the fastest and most effective possible. In the age of the cattle, there are 2 groups:

\section{Major emergencies in the calf:}

The neonatal diarrhea is the leading cause of neonatal mortality (Houffschmitt et al., 2004; Koch and Kaske, 2008). The importance is both economic and health (Joly, 2007). They can cause dehydration very often at the origin of the death of the animal in 6 to 12 hours (Rovary and Sattler, 2006). A quick intervention of the veterinarian is vital for the survival of the animal.

The risk of diarrhea is highest during the first week after calving (4th - 10th day) (Lorenz, 2007). The incidence of diarrhea in calves of less than 30 days varies from 15 to $20 \%$ and the risk of mortality is 1.5 to $8 \%$ (Koch and Kaske, 2008). The etiologic agents are numerous and differ depending on the age of the animal (CastroHermida et al., 2002; Dufrasne and Istasse, 1995; 
Hill and Jonhson, 1992; Houe et al., 2001; Ravary and Sattler, 2006): E. coli serotypes 157, H7, 026 and 0111 Cryptosporidium sp. BVD/MD virus.

The anoxia of calf is a complete lack of oxygenation. It is common during fetal life or in the birth, and it's the one of the major causes of neonatal mortality $(<24-48$ hours). These neonatal septicemia, are due to the movement of pathogens (Gram - (E. coli, Pseudomonas, Klebsiella, Salmonella, Campylobacter), or the Gram+ (Staphylococcus, Streptococcus, Corynebacterium and Actinomyces) in the blood, with one or several organs (Fecteau et al., 1997, Houe et al., 2001) is reached. E. coli is the most frequently isolated agent, originally from a rate of morbidity and lethality among calves over 3 days. The survival rate is only $12 \%$. Affected calves are on average between the ages of 3-5 days (Aldridge et al., 1993; Castro-Hermida et al., 2002; Constable et al., 1991).

\section{The medical emergencies major in the bovine adult:}

Among metabolic pathologies, puerperal hypocalcemia (milk fever, milk coma or calving fever), can lead to death of the animal in 12 to 24 hours and it is why is it a medical emergency (Sachot and Pouliquen, 2006). Predisposing factors are age (especially $3^{\text {rd }}$ lactation), the conduct of livestock (excess of calcium and phosphorus, magnesium deficiency), the level of production (high production), peri-partum cows (colostrum seeks a strong mobilization of calcium. race, the state of overweight (the damage in liver limiting the transformation of vitamin $\mathrm{D}_{3}$ (Audabie-Ladrix, 2005; Hill and Jonhson, 1992; Hunt, 1993; Lorenz, 2007), and season and recidivism (Hill and Jonhson, 1992)

Grass tetany is characterized by the brutal drop in concentration in the cerebrospinal fluid magnesium and translates by convulsive nervous signs, sometimes sudden death. The dairy cows or lactating in grazing and high producing or in gestation are most susceptible because magnesium is exported for the fetus or milk (Brugeres-Picouxj, 2004; Dufrasne and Istasse, 1995; Eddy, 2004; Graaf, 1999; Hunt, 1993; Naciri et al., 1999; Parez, 1985). The feeding of ruminants with condensed rations (crushed and agglomerated), containing 30 to $80 \%$ of cereals, allows obtaining very rapid growth. However, it causes various disorders, including bloat, is one of the most serious. Most often it is linked to the massive ingestion of legumes at certain stages of vegetation,

In fact the paramount factor is blocking eructation that may result from the presence of toxic substances in the fodder, usually linked to a nervous phenomenon: the eructation reflex is blocked when the level of the cardia is exceeded by the contents of the rumen. The ruminal digestive disorders can be caused by a considerable release of gases (simple indigestion), or by excessive accumulation of food materials (indigestion with overload).

The indigestion the baddest and the indigestion the most terrible that ruminants are experiencing is, without a doubt, that resulting from drying of foods (obstruction or craze of the slip) sheet (Brugeres-Picouxj, 2004). The resulting for an impact on ruminal distension may be due to the ingestion of sand or an energy poor ration, rich in roughage. It is more common during the dry season (more green fodder) with a diet composed of very dry fodder.

Distension is rather left centrally and the ruminal content has a harder consistency. Animals become weak, lose appetite, and decreased milk production (Brugeres-Picouxj, 2004). Finally, the abomasites may have a parasitic origin (Ostertagia SP., Haemonchus SP., Trichostrongylus $S P$.), traumatic or by Ingestion of soil or sand or food too finely divided.

Among infectious diseases, it is especially mastitis that poses the most problems. There are 2 types, the sub-clinical and the clinic. Clinical mastitis is coliforms types (Escherichia, Klebsiella, and Enterobacter) or gangrenous (Clostridium or Staphylococcus). If the infection goes up to toxemia, the animal is in shock with quick death): $3 / 4$ of affected animals from a clinical form with bacteremia are died (medical emergency).

The overall objective of cattle is the obtaining of a pregnant cow soon as possible and in the best economic conditions. The diseases most often encountered in the farms are those related to reproduction: metritis, non-delivery, dystocia/csection, reversal of matrix.

The mortality of calves in the center of the concerns for farmers because it degrades the herd productivity. Early embryonic mortality is often due to the IBR, BVD and later ( $>180$ days) to leptospirosis or neosporosis. In the best 
conditions for breeding, up to $15 \%$ of dairy cows suffer from infertility; $40 \%$ for infections genital and general, $25-30 \%$ for food errors and hygienic $20 \%$ for hereditary factors, $7-15 \%$ for accidents and sporadic factors (Hill and Jonhson, 1992).

The retained placenta, the dystocia, the ovarian disorders are also greatly involved in fertility reduction. For the cow, the dystocia are consequences in increased sterility, predisposition to puerperal diseases and a reduction in fertility. Born following a difficult calving is one of the factors of risk of complications for the calf the better recognized and having the greatest impact (Joly, 2007). There are of maternal origin from those of fetal origin dystocia. The majority of the authors confirmed the reduction of 6 to $15 \%$ of the rate of success in first insemination of cows who have submitted an infection of the genital tract (Aldridge et al., 1993).

The effect of the metritis is more serious if she is diagnosed after the 20th day postpartum. The retention adnexal or 'placental retention' or 'non-issue', is a classic complication of parturition in cattle, characterized by prolonged persistence of fetal envelope in the uterus after calving. It is a multifactorial disease, what explains the difficulties of its control.

Abortion (interruption of gestation regardless the stage) in a case on two is of infectious origin, (viruses, bacteria, parasites), but the causes of food (deficiencies, toxic substances) traumatic, genetic, anatomical can also cause abortions (Aldridge et al., 1993). Finally, many substances are likely to poison cattle. The most frequent are plants (plants cyanogenic / if / fern) and the products on the farm (drugs, insecticides, herbicides, fertilizers, food supplements).

Tab. 1. Summary of recorded diseases

\section{MATERIALS AND METHODS}

Our work of field, directed in several communes of the region of the center of the Algeria interested 30 veterinary practitioners in beef industry (questionnaire). The questionnaire, after identification of the veterinarian and its area of activity, must specify all measures undertaken of prophylaxis (vaccination and deworming program) and all of emergency situations encountered.

\section{RESULTS AND DISCUSSION}

After operation of the questionnaire data distributed to practitioners of the beef sector (table 1 ), the veterinarian, in the daily the exercise of its activity in the field its met pathologies very various. The diseases diagnosed, affect virtually all major functions. It is, in order of decreasing importance of pathologies affecting the reproductive system (31\%), the unit digestive (28\%), locomotor (13\%) and other pathologies (17\%) and, finally, the respirator (11\%) device (RAC 1).

The reproductive pathologies that constitute $31 \%$ of the total registered are represented by dystocia and mastitis with respectively 10 and 12 cases, and the metritis and retained placenta is only one case each. According to a document published in 2010 by the Institute of small farms, diseases of reproductive are funded in $50 \%$ of farms. They are represented by abortions, metritis, the problems of non-delivery, dystocia/caesarean section, and the overthrow of matrix. They affect, in 95\% cases, only a small proportion of breeding of the herd. The mastitis is the health disorders most common and the biggest economic impact in dairy farming.

\begin{tabular}{|c|c|c|c|c|c|c|c|}
\hline Apparatus & \multicolumn{7}{|c|}{ Diseases } \\
\hline Reproductive $23(31 \%)$ & \multicolumn{2}{|c|}{$\begin{array}{c}\text { Dystocia } \\
11 \text { cas }(41 \%) \\
\end{array}$} & \multicolumn{2}{|c|}{$\begin{array}{c}\text { Mastitis } \\
10 \text { cas }(46 \%) \\
\end{array}$} & \multicolumn{3}{|c|}{$\begin{array}{cc}\text { Metritis retained } & \text { placenta } \\
1 \text { cas }(6,5 \%) & 1 \text { cas }(6,5 \%) \\
\end{array}$} \\
\hline Digestive 22 (28\%) & $\begin{array}{l}\text { Weathering } \\
14 \text { cas }(64 \%)\end{array}$ & $\begin{array}{l}\text { Ent } \\
2 \mathrm{c}\end{array}$ & $\begin{array}{l}\text { eritis } \\
\text { as }(9 \%)\end{array}$ & $\begin{array}{r}\text { Acid } \\
2 \text { ca }\end{array}$ & sis & $\begin{array}{l}\text { Diarrhea } \\
2 \text { cas }(9 \%)\end{array}$ & $\begin{array}{r}\text { Indigestion } \\
2 \text { cas }(9 \%) \\
\end{array}$ \\
\hline Respiratory $\mathbf{8}(11 \%)$ & \multicolumn{7}{|c|}{$\begin{array}{c}\text { Bronchopneumonia } \\
8 \text { cas }(11 \%) \\
\end{array}$} \\
\hline Musculoskeletal system 10 (13\%) & \multicolumn{5}{|c|}{$\begin{array}{l}\text { Whitlow } \\
6 \text { cas }(60 \%)\end{array}$} & \multicolumn{2}{|l|}{$\begin{array}{c}\text { Lameness } \\
4 \text { cas }(40 \%)\end{array}$} \\
\hline Other $13(17 \%)$ & $\begin{array}{l}\text { RPT } \\
1 \text { cas }(9 \%)\end{array}$ & $\begin{array}{l}\text { Hypoc } \\
9 \text { cas }(\end{array}$ & $\begin{array}{l}\text { lcemia } \\
8 \%)\end{array}$ & $\begin{array}{l}\text { Pericar } \\
1 \text { cas }(\end{array}$ & $\begin{array}{ll}\text { ditis } & \mathrm{H} \\
3 \%) & 1\end{array}$ & $\begin{array}{l}\text { Hypomagnesemia } \\
1 \text { cas }(8 \%)\end{array}$ & $\begin{array}{c}\text { Scab } \\
1 \text { cas }(8 \%)\end{array}$ \\
\hline
\end{tabular}


This is mainly because of their frequency and costs veterinary they entail (fees, cost of treatment) and their negatively impact both qualitative and quantitative milk production (Coulon and Lescourret, 1997; Guerin-Faublee, 2003).

Among digestive diseases, indigestion is a generic term for all malfunctions of the rumennetwork (reticulum-rumen). Some of this indigestion is the true emergencies: veterinarian intervention must therefore be as early as possible and the prognosis is often committed (Kellin et al., 2002). Digestive diseases constitute $28 \%$ of the listed diseases. The interviewed veterinarians have recorded 14 cases of meteorisations and as many cases of enteritis, acidosis, diarrhea and indigestion ( 2 cases). The bloat can occur anytime during the grazing season. We should always be on the lookout, because the bloat of grazing properties can change rapidly (Brugeres-Picouxj, 2004).

The $11 \%$ of cases of respiratory diseases are represented exclusively by the infectious bronchopneumonia. They are one of the major cattle health problems, because of the fragility of their lungs and the highly contagious nature of responsible microbes, which can take significant proportions. The bovine bronchopneumonia is a set of common multifactorial diseases in livestock. Depending on the age of the animal, we talk about B.P.I.E (bronchopneumonia infectious Enzootique) for older animals for fattening (often a few weeks after the lot). It is a disease that has a clinical and economic impact on farms (Joly, 2007).

The results show that $13 \%$ of diseases encountered in the field affect musculoskeletal which 6 cases of Paronychia and 4 cases of lameness. The Paronychia is the infection necrotizing acute or subacute of the soft tissues of the interdigital space. Its appearance is brutal. This affection is responsible for a significant portion of lameness (15-25\%), and can occur at any age (including calves), more frequently after calving (BrugeresPicouxj, 2004). According to the weekly newspaper agricultural (february 2010), breastfeeding and dairy farming, the livestock lameness represent a common disorder. The discomfort of the animals can lead to economic losses.

Thus, among the pathologies clinics identified the lameness cattle arrive in second place, behind mastitis. It is estimated that $13 \%$ of cows are affected, each year in France (Coulon and Lescourret, 1997). Taking into account the time spent for care, veterinary expenses and decreases in performance, economic losses are rapidly important for breeding.

The $17 \%$ of remaining pathologies are diverse. A number are present on the ground, namely: hypocalcemia ( 9 cases/13) and, of equal importance (1 case on 13), RPT, pericarditis, the hypomagnesemia and ringworm. According to

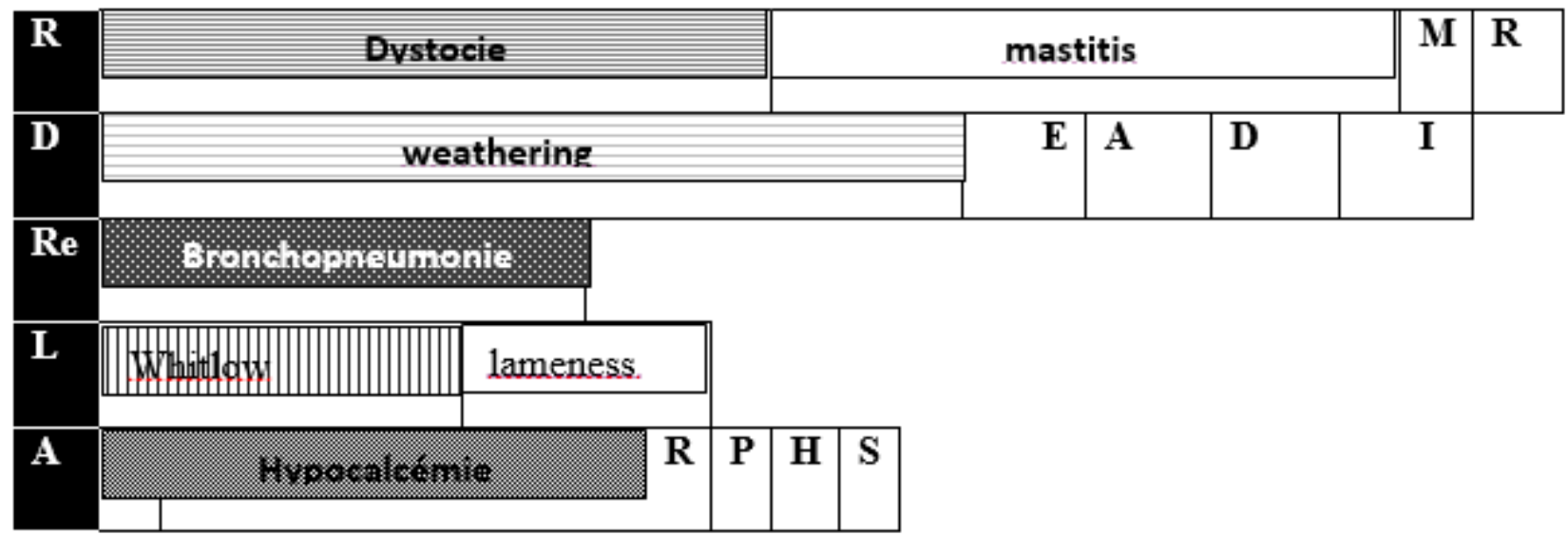

\begin{tabular}{|l|l|l|l|l|l|l|l|l|l|l|l|l|l|l|l|l|l|l|l|l|l|l|}
1 & 2 & 3 & 4 & 5 & 6 & 7 & 8 & 9 & 10 & 11 & 12 & 13 & 14 & 15 & 16 & 17 & 18 & 19 & 20 & 21 & 22 & 23 \\
\hline
\end{tabular}

number of cases

$\mathrm{R}=$ Reproductive $/ \mathrm{D}=$ Digestive $/ \mathrm{Re}=$ respiratory $/ \mathrm{L}=$ musculoskeletal system $/ \mathrm{A}=$ other.

$\mathrm{M}=$ Metritis $/ \mathrm{R}=$ placenta retention $/ \mathrm{E}=$ Enteritis $/ \mathrm{A}=$ Acidosis $/ \mathrm{D}=$ diarrhea $/ \mathrm{I}=$ Indigestion.

$\mathrm{R}=$ Reticulo-peritonite traumatic/ $\mathrm{P}=$ Pericarditis $/ \mathrm{H}=$ Hypomagnesemia/ $\mathrm{S}=\mathrm{scab}$.

Fig. 1. Diagram of the main pathologies encountered on the ground in beef industry 
Redah (2007), milk fever or hypocalcemia strikes on average $7 \%$ of dairy cows in Algeria, mainly animals at high milk production as early as their second calving. The risk of recidivism during the following calving is strongly increased

\section{CONCLUSION}

At the end of our study, several lessons can be highlighted:

- an enrichment on the practical (technical \& scientific) and even relational.

- the audit of the places highlighted different emergencies in bovine medicine.

After operation of the data registered with the veterinary practitioners of the beef sector, in the area of the center of the Algeria, it is noted that diagnosed diseases, affect virtually all major functions.

It is, in order of decreasing importance of pathologies affecting the reproductive system (metritis and retained placenta) [31\%], the digestive tract (meteorisations, enteritis, acidosis, diarrhea and indigestion) (28\%), musculoskeletal (Paronychia and lameness) [13\%] and other pathologies (hypocalcemia, RPT, pericarditis, hypomagnesemia and Tinea) [17\%] and finally, the respiratory tract (B.P.I.E = bronchopneumonia infectious enzootic) [11\%],

It is obvious, that it is necessary that measures health and medical reasoned must be strengthened in order to hope to improve farming conditions and thus, increase the productivity of our farms.

\section{REFERENCES}

1. Aldridge B, Garry F, Adams R (1993). Neonatal septicemia in calves: 25 cases (1985-1990). J of American Veterinary Medicine Association 9:1324-1329.

2. Aubadie-Ladrix M (2005). Abord pratique d'une fièvre vitulaire chez la vache. Le Point Vétérinaire 257:40-42.

3. Brugeres-Picouxj (2004.) Maladies des moutons, 2 ème édition. France Agricole.

4. Caple IW, West DM (1993). Ruminant hypomagnesemic tetanies. In: Howard JL (ed). Current veterinary therapy food animal practice, third edition, WB Saunders Company, Philadelphia, 318-321.

5. Castro-Hermida J, Gonzalez-Losada Y, MezoMenendez M, Ares-Mazas E (2002). A study of cryptosporidiosis in a cohort of neonatal calves. Veterinary Parasitology 106:11-17.

6. Constable PD, Schmall LM, Muir W, Hoffsis GF(1991). Respiratory, renal, hematologic, and serum biochemical effects of hypertonic saline solution in endotoxemic calves. American Journal of Veterinary Research 52(7):990-998.
7. Coulon JB, Lescourret F (1997). Effet des mammites cliniques sur la production des vaches laitiéres. Renc Rech Ruminants 4 :265-268.

8. Dufrasne I, Istasse L (1995). L'axe sol-plante-herbe dans les tétanies d'herbe. Annales de Médecine Vétérinaire $139: 403-410$.

9. Eddy RG (2004). Major metabolic disorders. In: Andrews AH, Blowey R, Boyd H, Eddy RG (editors). Bovine medicine diseases and husbandry of cattle, 2nd edition, Blackwell Science, Oxford, 781-803.

10. Fecteau G, Van Metre D, Smith BP, Higgins R, Holmberg CA, Jang S, Guterbock W (1997). Bacteriological culture of blood from critically ill neonatal calves. Canadian Veterinary Journal 38:95-100.

11. Graaf DC (1999). A review of the importance of cryptosporidiosis in farm animals. International Journal for Parasitology 29:1269-1287.

12. Greene LW, Baker JF, Hardt PF (1989). Use of animal breeds and breeding to overcome the incidence of grass tetany: a review. J of Animal Sc 67:3463-3469.

13. Guerin-Faublee V (2003). In vitro activity of 10 antimicrobial agents against bacteria isolated from cows with clinical mastitis. Veterinary Record 152:466-471.

14. Hill BD, Jonhson RB (1992), Pasteurella multocida septicaemia in two calves. Australian Veterinary Journal 69(8):197-198.

15. Houe H, Ostergaard S, Thilsing-Hansen T, Jorgensen RJ (2001). Milk fever and subclinical hypocalcaemia. An evaluation of parameters on incidence risk, diagnosis, risk factors and biological effects as input for a decision support system for disease control. Acta Vet Scand 42:129.

16. Houffschmitt P, Thomas E, Beaussart F (2004). La septicémie du veau: moins d'inconnues. Le Point Vétérinaire 243:40-42.

17. Hunt E (1993). Diarrhoeal diseases of neonatal ruminants. In: Howard JL (ed). Current veterinary therapy food animal practice, third edition, WB Saunders Company, Philadelphia, 103-109.

18. Joly J (2007). Le péripartum de la vache laitière : aspects zootechniques et sanitaires. Thèse Méd Vét Alfort 258.

19. Kelling CL, Steffen D, Cooper VL, Higuchi DS, Eskridge K (2002). Effect of infection with bovine viral diarrhea virus alone, bovine rotavirus alone, or concurrent infection with both on enteric disease in gnotobiotic neonatal calves. American Journal of Veterinary Research 63:1179-1186.

20. Koch A, Kaske M (2008). Clinical efficacy of intravenous hypertonic saline solution or hypertonic bicarbonate solution in the treatment of inappetent calves with neonatal diarrhea. Journal of Veterinary Internal Medicine 22:202-211.

21. Lorenz I (2007). D-lactic acidosis in calves. The Veterinary Journal 179(2):197-203.

22. Naciri M, Lefayc MP, Mancassolaa R, Poirier P, Chermetted $\mathrm{R}$ (1999). Role of Cryptosporidium parvum as a pathogen in neonatal diarrhoea complex in suckling and dairy calves in France. Vet Parasit 85:245-257. 
23. Parez M (1985). Les plus importantes maladies génitales des bovins (prophylaxie, traitement, hygiène de la récolte du sperme). Rev Sci Tech Off Int Epiz 4 (1) :45-68.

24. Ravary B, Sattler N (2006). Septicémie et bactériémie. In: Néonatalogie du veau. Les éditions du Point Vétérinaire, Rueil-Malmaison., 121-134.
25. Sachot E, Pouliquen H (1998). Intoxications des ruminants par les herbicides, fungicides et fertilisants. Le Point Vétérinaire 29(numéro special):1273-1278. 